\title{
PENGARUH PENGETAHUAN DAN KESADARAN WAJIB PAJAK TERHADAP KEPATUHAN WAJIB PAJAK DALAM MEMBAYAR PAJAK BUMI DAN BANGUNAN (PBB) PADA KANTOR BADAN PENDAPATAN DAERAH KOTA PEKANBARU
}

\author{
Oleh: Wenny Desty Febrian ${ }^{1}$, Ristiliana ${ }^{2}$, Romadina Permatasari ${ }^{3}$ \\ Manajemen-UIN Suska Riau ${ }^{1}$, Pendidikan Ekonomi-UIN Suska Riau ${ }^{2}$, Pendidikan Ekonomi-UR $^{3}$ \\ Email: ${ }^{1}$ wenny.desty.febrian@uin-suska.ac.id, ${ }^{2}$ ristiliana@uin-suska.ac.id
}

\begin{abstract}
Abstrak
Penelitian ini dilaksanakan di Kantor Badan Pendapatan Daerah (BAPENDA) Kota Pekanbaru. Penelitian ini bertujuan untuk mengetahui pengaruh tingkat pengetahuan dan kesadaran wajib pajak terhadap kepatuhan wajib pajak dalam membayar Pajak Bumi dan Bangunan (PBB) pada Kantor Badan Pendapatan Daerah (BAPENDA) Kota Pekanbaru. Penelitian ini merupakan penelitian survey dengan pendekatan kuantitaif. Data penelitian ini dikumpulkan melalui kuesioner/angket dan kemudian dianalisis menggunakan analisis regresi linear berganda. Berdasarkan hasil analisis dapat disimpulkan bahwa tingkat pengetahuan dan kesadaran wajib pajak berpengaruh positif terhadap kepatuhan wajib pajak. Hal ini dibuktikan melalui analisis regresi linier berganda yang diperoleh nilai Adjusted R Square sebesar 0,720, yang dapat diartikan bahwa pengaruh pengetahuan dan kesadaran wajib pajak terhadap kepatuhan wajib pajak adalah $72 \%$, sedangkan sisanya sebesar $28 \%$ dipengaruhi oleh variabel lain di luar penelitian ini, seperti kualitas pelayanan, tingkat penghasilan dan persepsi wajib pajak terhadap sanksi. Hasil uji t statistik juga menghasilkan nilai signifikansi lebih kecil dari of significant yaitu $0,000<0,05$. Besarnya nilai koefisien regresi $X_{1}$ 0,029 dan $X_{2}$ 0,860 dengan bilangan kostanta 9,988. Persamaan garis regresinya adalah $Y=9,988+0,029 X_{1}+0,860 X_{2}$. Hal ini berarti semakin tinggi tingkat pengetahuan dan kesadaran wajib pajak maka semakin tinggi kepatuhan wajib pajak.
\end{abstract}

\section{Kata Kunci: Pengetahuan, Kesadaran Wajib Pajak, Kepatuhan Wajib Pajak}

\begin{abstract}
This research was conducted at the Office of the Regional Revenue Agency (BAPENDA) of Pekanbaru City. This study aims to determine the effect of the level of knowledge and awareness of taxpayers on taxpayer compliance in paying Land and Building Tax (PBB) at the Office of Regional Revenue Agency (BAPENDA) of Pekanbaru City. This research is a survey research with a quantitative approach. The data of this study were collected through questionnaires and then analyzed using multiple linear regression analysis. Based on the results of the analysis it can be concluded that the level of knowledge and awareness of taxpayers has a positive effect on taxpayer compliance. This is evidenced through multiple linear regression analysis which obtained the value of Adjusted $R$ Square of 0.720, which can be interpreted that the effect of knowledge and awareness of taxpayers on taxpayer compliance is $72 \%$, while the remaining $28 \%$ is influenced by other variables outside of this study, such as service quality, income level and taxpayer's perception of sanctions. The results of the t-test statistics also produce a significance value smaller than significant, namely 0,000 $<0,05$. The magnitude of the regression coefficient X1 0.029 and X2 0.860 with the costing number 9.988. The regression line equation is $Y=9.988+0.029 X 1+0.860 X 2$. This means that the higher the level of knowledge and awareness of the taxpayer, the higher the taxpayer's compliance.
\end{abstract}

Keywords: Knowledge, Taxpayer Awareness, Taxpayer Compliance 


\section{PENDAHULUAN}

Perekonomian suatu negara mempunyai sumber pembiayaan pembangunan nasional berbentuk pajak, yang diperuntukkan dalam usaha peningkatan masyarakat. Di mana pajak memiliki peran yang sangat penting terhadap pendapatan negara pada masa sekarang. Ini terjadi karena adanya pajak,dan sumber yang pasti dalam memberikan kontribusi kepada negara. Pajak Bumi dan Bangunan merupakan jenis pajak daerah yang sepenuhnya diatur oleh pemerintah dalam menentukan besar pajaknya, pajak ini penting untuk pelaksanaan dan peningkatan pembangunan serta meningkatkan kemakmuran dan kesejahteraan rakyat (Amanah, 2015). Oleh karena itu perlu adanya peningkatan peran serta masyarakat.

Bumi dan bangunan memberikan keuntungan dan kedudukan sosial ekonomi yang lebih baik bagi orang/badan yang mempunyai suatu hak atasnya atau memperoleh manfaat darinya (Jati, 2016). Oleh sebab itu, mereka diwajibkan untuk memberikan sebagian dari manfaat yang diperolehnya kepada negara melalui pajak. Hasil penerimaan Pajak Bumi dan Bangunan (PBB) ditujukan untuk kepentingan masyarakat daerah yang diduduki (Hidayanti, 2011).

Pemerintah Daerah setiap tahunnya mempunyai ketetapan dalam penerimaan Pajak Bumi dan Bangunan (PBB) sebagai sumber Pendapatan Asli Daerah (PAD), tetapi ketetapan tersebut tidak selalu terealisasi dengan sempurna (Rahmawan, 2012).
Realisasi penerimaan Pajak Bumi dan Bangunan terkadang jauh dibawah target yang telah ditetapkan.

Tabel 1 Tingkat Penerimaan Pajak Bumi dan Bangunan Kota Pekanbaru Tahun 2014 - 2018

\begin{tabular}{|l|l|l|l|}
\hline & Target Penerimaan & & Persentase \\
Tahun & Pajak & Realisasi PBB & $\begin{array}{c}\text { Pencapaian } \\
(\%)\end{array}$ \\
\hline 2014 & Rp. 51.746 .624 .037 & Rp. $41,999,306,880$ & 81,16 \\
\hline 2015 & Rp. 127.390 .009 .150 & Rp. $58,234,415,203$ & 45,71 \\
\hline 2016 & Rp. 104.212 .342 .760 & Rp. $60,446,308,650$ & 58,00 \\
\hline 2017 & Rp. 104.212 .342 .806 & Rp. 60.868 .387 .186 & 58,41 \\
\hline 2018 & Rp. 191.765016 .227 & Rp. 66.207 .610 .973 & 34,53 \\
\hline
\end{tabular}

Sumber: BAPENDA Kota Pekanbaru, (2018)

Dari tabel 1 di atas dapat dilihat bahwa persentase penerimaan Pajak Bumi dan Bangunan (PBB) mengalami penurunan dan kenaikan, dan belum tercapai realisasi dengan sempurna. Terlihat sejak tahun 2015 mulai terjadi penurunan persentase realisasi Pajak Bumi dan Bangunan namun terjadi sedikit kenaikan pada tahun 2017 dan penurunan persentase penerimaan Pajak Bumi dan Bangunan terendah terjadi di tahun 2018.

Tabel 2 Tingkat Kepatuhan Wajib Pajak PBB Di Kota Pekanbaru Tahun 2014-2018

\begin{tabular}{|c|c|c|c|}
\hline Tahun & SPPT & Realisasi & $\begin{array}{c}\text { Pencapaian } \\
(\%)\end{array}$ \\
\hline 2014 & 43.636 & 38.737 & 88,77 \\
\hline 2015 & 61.919 & 52.361 & 84,56 \\
\hline 2016 & 80.467 & 54.954 & 68,29 \\
\hline 2017 & 100.272 & 54.798 & 54,64 \\
\hline 2018 & 121.164 & 63.649 & 52,53 \\
\hline
\end{tabular}

Sumber: BAPENDA Kota Pekanbaru, (2018) Berdasarkan tabel 2 terlihat bahwa persentase pencapaian tingkat kepatuhan wajib Pajak Bumi dan Bangunan tidak mencapai target penerimaan yang telah di tetapkan oleh pemerintah. Hal ini seharusnya menjadi perhatian bagi pemerintah Kota 
Pekanbaru karena penerimaan Pajak Bumi dan Bangunan (PBB) memiliki pengaruh terhadap Pendapatan Asli Daerah (PAD). Pada dasarnya faktor penghambat pembayar pajak adalah masalah kesadaran masyarakat, di mana masyarakat perlu diberi pengarahan bahwa pajak merupakan kewajiban dan hak setiap warga negara untuk ikut serta dalam pembangunan. Jika kesadaran Wajib Pajak tinggi yang berasal dari motivasi untuk membayar pajak, maka kepatuhan untuk membayar pajak pun akan tinggi dan pendapatan untuk daerah sektor pajak semakin meningkat.

Menurut Tjahjono (2008) kepatuhan wajib pajak adalah perilaku wajib pajak dalam memenuhi kewajiban perpajakannya sesuai dengan peraturan yang berlaku. Sedangkan menurut Purnamasari (2016), kepatuhan pajak yaitu apabila wajib pajak yang taat dan memenuhi serta melaksanakan kewajiban perpajakan sesuai dengan ketentuan peraturan perundang-undangan perpajakan.

Sehingga kepatuhan wajib pajak adalah wajib pajak yang taat dan memenuhi serta melaksanakan kewajiban perpajakan sesuai dengan ketentuan perundang- undangan perpajakan yang berlaku. Beberapa faktor yang mempengaruhi kepatuhan wajib pajak menurut Yusnidar (2015) yaitu:

1.Pengetahuan wajib pajak, yaitu wajib pajak harus meliputi pengetahuan mengenai Ketentuan Umum dan Tata Cara Perpajakan, pengetahuan mengenai Sistem Perpajakan di Indonesia dan pengetahuan mengenai fungsi perpajakan. Pengetahuan pajak sendiri pada umumnya terkait dalam tingkat pendidikan seseorang, orang yang memiliki pengetahuan perpajakan lebih tinggi akan memiliki kepatuhan lebih tinggi karena selain mereka tarif pajak yang dibebankan kepada mereka, mereka juga mengetahui bahwa jika mereka tidak melaksanakan kewajiban mereka sebagai wajib pajak mereka akan terkena sanksi atapun denda.

2.Kesadaran wajib pajak dalam membayar. Kewajiban pajak akan meningkat bilamana dalam masyarakat muncul persepsi positif terhadap pajak. Meningkatnya pengetahuan perpajakan masyarakat melalui pendidikan perpajakan baik formal maupun non formal akan berdampak positif terhadap kesadaran wajib pajak untuk membayar pajak. Penyuluhan pajak yang dilakukan secara intensif dan kontinyu akan dapat meningkatkan pemahaman wajib pajak tentang kewajiban membayar pajak sebagai wujud kegotong royongan nasional dalam menghimpun dana untuk kepentingan pembiayaan pemerintahan dan pembangunan nasional .

3.Kualitas Pelayanan. Kualitas pelayanan perpajakan dalam Pajak Bumi dan Bangunan Perdesaan dan Perkotaan berdasarkan definisi diatas dapat disimpulkan menjadi dua bagian, yaitu: a) Metode Penyampaian SPPT Mekanisme penyerahan SPPT dari Dinas Pendapatan dan Pengelolaan Aset Daerah yang disalurkan kepada kantor kelurahan sesuai domisili Wajib Pajak, ketua 
RW, Ketua RT dan untuk disampaikan kepada wajib pajak. b) Pelayanan pembayaran PBB-P2 yakni mekanisme pembayaran yang dibuat sesederhana mungkin, wajib pajak hanya perlu membawa sejumlah nominal pajak terutangnya beserta SPPT PBB-P2 jika membayar di kelurahan, jika membayar di bank wajib pajak akan dibantu oleh petugas bank. Selain itu fasilitas-fasilitas yang mendukung proses pembayaran yang meningkatkan kenyamanan Wajib Pajak dalam membayar PBB-P2 harus lebih ditingkatkan serta lokasi pembayaran yang cukup mudah di jangkau oleh Wajib Pajak yang ingin membayar juga merupakan bagian dari pelayanan.

4.Tingkat Penghasilan, akan mempengaruhi kepatuhan wajib pajak dalam membayar pajak tepat pada waktunya. Kemampuan Wajib Pajak dalam memenuhi kewajiban pajak terkait erat dengan bersama penghasilan, maka salah satu hal yang di pertimbangkan dalam pemungutan pajak adalah penghasilan.

5.Persepsi wajib pajak terhadap sanksi. Sanksi ditujukan kepada wajib pajak yang tidak mematuhi aturan perpajakan atau melakukan pelanggaran berupa kecurangan terhadap peraturan perpajakan yang berlaku saat ini. Sanksi perpajakan terjadi karena terdapat pelanggaran terhadap peraturan perundangundangan perpajakan. Sehingga apabila terjadi pelanggaran maka wajib pajak dihukum dengan indikasi kebijakan perpajakan dan undang-undang perpajakan.
Dalam undang-undang perpajakan dikenal dua macam sanksi, yaitu sanksi administrasi dan sanksi pidana. Sanksi administrasi dikenakan tehadap wajib pajak yang tidak memenuhi ketentuan peraturan perpajakan atau melakukan pelanggaran terhadap peraturan perpajakan yang berlaku, sanksi administrasi berupa pembayaran kerugian pada negara, dapat berupa bunga, denda, atau kenaikan.

Menilik pada faktor-faktor yang mempengaruhi kepatuhan wajib pajak maka salah satu yang menjadi sorotan ialah faktor pengetahuan dan kesadaran wajib pajak. Kedua faktor ini merupakan faktor penting karena jika mereka tidak memiliki pengetahuan, maka mereka akan menjadi wajib pajak yang tidak memiliki kesadaran akan membayar pajak. Sebagaimana diungkapkan oleh Rahayu (2010), yaitu wajib pajak harus meliputi pengetahuan mengenai Ketentuan Umum dan Tata Cara Perpajakan, pengetahuan mengenai Sistem Perpajakan di Indonesia dan pengetahuan mengenai fungsi perpajakan.

Dalam penelitian ini yang dimaksud pengetahuan pajak antara lain adalah sejauh mana wajib pajak mengetahui fungsi PBB sebagai salah satu sumber pendapatan di Kota Pekanbaru, terlebih lagi dengan adanya UU No. 28 tahun 2009 mengenai pengelolaan PBB dari pusat ke daerah menjadi $100 \%$ penerimaan daerah berpotensi menjadi sumber pendapatan yang sangat signifikan bagi daerah. Pengetahuan pajak sendiri pada 
umumnya terkait dalam tingkat pendidikan seseorang, orang yang memiliki pengetahuan perpajakan lebih tinggi akan memiliki kepatuhan lebih tinggi karena mereka memikirkan tarif pajak yang dibebankan kepada mereka dan juga sanksi atau denda yang akan diterima apabila melanggar (Yusnidar,2015).

Sedangkan faktor lain yang penting dan menjadi sorotan dalam dunia perpajakan yaitu kesadaran wajib pajak. Kesadaran merupakan unsur dalam diri manusia untuk memahami realitas dan bagaimana mereka bertindak atau bersikap terhadap realitas. Jatmiko (2016) menjelaskan bahwa kesadaran adalah keadaan mengetahui atau mengerti. Irianto (2012) menguraikan beberapa bentuk kesadaran membayar pajak yang mendorong wajib pajak untuk membayar pajak.

Pertama, kesadaran bahwa pajak merupakan bentuk partisipasi dalam menunjang pembangunan negara. Kedua, kesadaran bahwa penundaan pembayaran pajak dan pengurangan beban pajak sangat merugikan negara. Ketiga, kesadaran bahwa pajak ditetapkan dengan Undang-undang dan dapat dipaksakan.

Kesadaran perpajakan seringkali menjadi kendala dalam masalah pengumpulan pajak dari masyarakat. Secara empiris juga telah dibuktikan bahwa makin tinggi kesadaraan perpajakan wajib pajak maka akan makin tinggi tingkat kepatuhan wajib pajak(Suyatmin,2010 dalam Jatmiko, 2011).

Kesadaran Wajib Pajak berkaitan dengan
Pajak Bumi dan Bangunan adalah (Tjiptohadi, 2015):

1.Sebagai orang yang memperoleh manfaat atas bumi dan bangunan wajib pajak memiliki kewajiban dalam membayar pajak atas objek yang mereka miliki/manfaatkan.

2.Wajib pajak sadar bahwa pajak merupakan sumber pendapatan daerah, jadi sebagai warga negara yang merupakan bagian dari sebuah daerah kesadaran membayar pajak juga dapat diartikan kesadaran untuk turut serta dalam pembangunan daerah.

Seorang yang memiliki kesadaran akan wajib pajak Menurut Jati (2016), dapat diidentifikasikan sebagai berikut :1). Sadar bahwa membayar Pajak Bumi dan Bangunan adalah kewajiban warga Negara Indonesia; 2). Membayar Pajak Bumi dan Bangunan dengan tepat waktu; 3). Membayar Pajak Bumi dan Bangunan bukan merupakan beban; dan 4). Melaporkan apabila terdapat perubahan harta.

Berdasarkan masalah yang telah dipaparkan di atas, peneliti tertarik untuk melakukan penelitian yang mengkaji tentang "Pengaruh Pengetahuan dan Kesadaran Wajib Pajak terhadap Kepatuhan Wajib Pajak dalam membayar Pajak Bumi dan Bangunan (PBB) pada kantor Badan Pendapatan Daerah Kota Pekanbaru".

Berdasarkan latar belakang penelitian yang telah diuraikan di atas maka dirumuskan masalah sebagai berikut:

1.Apakah pengetahuan wajib pajak berpengaruh terhadap kepatuhan wajib 
pajak dalam membayar Pajak Bumi dan Bangunan (PBB) di Kota Pekanbaru?

2.Apakah kesadaran wajib pajak berpengaruh terhadap kepatuhan wajib pajak dalam membayar Pajak Bumi dan Bangunan (PBB) di Kota Pekanbaru?

3.Apakah pengetahuan wajib pajak dan kesadaran wajib pajak berpengaruh terhadap kepatuhan wajib pajak dalam membayar Pajak Bumi dan Bangunan (PBB) di Kota Pekanbaru?

Adapun tujuan dari penelitian ini adalah untuk mendapatkan bukti empiris tentang pengaruh pengetahuan wajib pajak dan kesadaran wajib pajak terhadap kepatuhan wajib pajak dalam membayar Pajak Bumi dan Bangunan (PBB) di Kota Pekanbaru. Sedangkan manfaat dari penelitian ini agar dapat menambah wawasan dan informasi bagi penulis dan pembaca tentang pengetahuan wajib pajak dan kesadaran wajib pajak terhadap kepatuhan wajib pajak dalam membayar Pajak Bumi dan Bangunan (PBB) dan bagi Badan Pendapatan Daerah (BAPENDA) kota Pekanbaru dapat berinovasi dalam mengembangkan teknologi untuk mengoptimalkan pelayanan terhadap wajib pajak.

Penelitian ini pada akhirnya akan menjawab hipotesis akhir yang peneliti bangun berdasarkan permasalahan dan teori yang ada yaitu: "Ada pengaruh positif yang signifikan antara pengetahuan wajib pajak dan kesadaran wajib pajak terhadap kepatuhan wajib pajak dalam membayar Pajak Bumi dan
Bangunan".

\section{METODE PENELITIAN}

\section{Jenis Penelitian}

Penelitian ini merupakan penelitian survey. Adapun pendekatan yang digunakan adalah pendekatan kuantitatif.

\section{Waktu dan Tempat Penelitian}

Penelitian ini dilakukan pada Kantor Badan Pendapatan Daerah (BAPENDA) Kota Pekanbaru. Waktu penelitian yaitu pada bulan November sampai dengan Desember 2018.

\section{Populasi dan Sampel Penelitian}

Populasi pada penelitian ini adalah adalah wajib Pajak Bumi dan Bangunan (PBB) yang terdaftar di Badan Pendapatan Daerah (BAPENDA) kota Pekanbaru pada tahun 2018, yaitu sebanyak 121.164. Sampel yang diambil dalam penelitian ini adalah wajib pajak sejumlah 100 orang dengan menggunakan teknik pemilihan probabilitas atau secara acak (Probability Sampling) dengan metode sampel acak sederhana.

\section{Prosedur Penelitian}

Penelitian ini dilakukan dengan memberikan kuesioner dengan skala likert kepada para responden yang telah terpilih sebagai sampel yang datanya dikelompokkan menjadi data primer. Menurut Sugiyono (2010), bentuk awal dari skala likert ini adalah lima pilihan jawaban dari yang sangat tidak setuju hingga sangat setuju yang merupakan jawaban dari seseorang maupun sekelompok 
orang atas suatu pertanyaan atau kejadian yang diberikan dalam kuisioner. Pilihan jawaban yang bisa dipilih oleh responden dalam penelitian ini adalah:

Skor 1 = Sangat tidak setuju

Skor 2 = Tidak setuju

Skor 3 = Kurang setuju

Skor $4=$ Setuju

Skor 5 = Sangat setuju

Selanjutnya untuk data sekunder diperoleh dari dokumen penerimaan Pajak Bumi dan Bangunan (PBB) yang ada pada Badan Pendapatan Daerah (BAPENDA).

\section{Teknik Pengumpulan Data}

Teknik yang digunakan untuk mengumpulkan data dalam penelitian ini adalah dengan menggunakan kuesioner. Kuesioner ini akan dibagikan pada Wajib Pajak Bumi dan Bangunan (PBB) Kota Pekanbaru dengan asumsi mereka mau menjawab semua pertanyaan yang telah disusun penulis. Sebelum melakukan penelitian, peneliti melakukan uji instrument terlebih dahulu yaitu menggunakan uji validitas dan uji reliabilitas.

\section{Teknik Analisis Data}

Metode analisis data menggunakan uji asumsi klasik, analisis regresi linier berganda dan uji hipotesis.

\section{a. Uji Asumsi Klasik}

Uji asumsi klasik yang dilakukan terhadap model regresi yang digunakan dalam penelitian digunakan untuk menguji apakah model tersebut baik atau tidak. Dalam penelitian ini peneliti menggunakan uji normalitas. Menurut Imam Ghozali (2011) Uji Normalitas data bertujuan untuk menguji apakah dalam model regresi berganda berdistribusi normal atau tidak normal.

\section{b.Uji Analisis Regresi Linier Berganda}

Analisis regresi linier berganda adalah hubungan secara linear antara dua atau lebih variabel independen $\left(\mathrm{X}_{1}, \mathrm{X}_{2}, \ldots \mathrm{X}_{\mathrm{n}}\right)$ dengan variabel dependen (Y). Analisis ini untuk mengetahui arah hubungan antara variabel independen dengan variabel dependen apakah masing-masing variabel independen berhubungan positif atau negatif dan untuk memprediksi nilai dari variabel dependen apabila nilai variabel independen mengalami kenaikan atau penurunan. Persamaan regresi linear berganda sebagai berikut:

$$
Y^{\prime}=a+b_{1} X_{1}+b_{2} X_{2}+\ldots . .+b_{n} X_{n}
$$

Keterangan:

$\mathrm{Y}^{\prime} \quad=$ Variabel dependen (nilai yang diprediksikan)

$X_{1}$ dan $X_{2}=$ Variabel independen

a $\quad=$ Konstanta (nilai $Y^{\prime}$ apabila $\mathrm{X}_{1}, \mathrm{X}_{2} \ldots . . \mathrm{X}_{\mathrm{n}}=0$ )

$\mathrm{b}=$ Koefisien regresi (nilai peningkatan ataupun penurunan)

\section{c.Uji Hipotesis}

Uji Signifikansi Parameter Individual (Uji Statistik t) Pengujian parameter individual dimaksudkan untuk melihat apakah variabel secara individu mempunyai pengaruh terhadap variabel tak bebas dengan asumsi variabel bebas lainnya konstan. 
Kriteria pengujian sebagai berikut:

1. Membandingkan antara $\mathrm{t}$ hitung dengan $\mathrm{t}$ tabel. Bila t hitung < t tabel, variabel bebas secara individual tidak berpengaruh terhadap variabel tak bebas. Bila thitung $>\mathrm{t}$ tabel, variabel bebas secara individual berpengaruh terhadap variabel takbebas.

2. Berdasarkan probabilitas signifikansi lebih kecil dari $0,05(\alpha)$, maka variabel bebas secara individu berpengaruh terhadap variabel dependen.

HASIL

PENELITIAN

DAN

\section{PEMBAHASAN}

1. Uji Normalitas Data

\section{Tabel 3 Hasil Uji Normalitas Data}

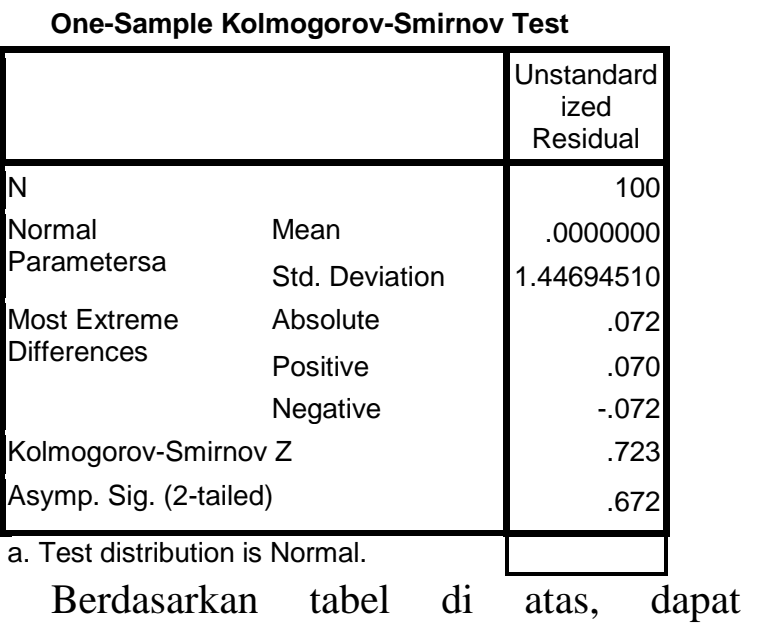

diketahui nilai signifikansi untuk varibel sebesar 0,672 yang berarti lebih besar dari 0,05, maka dapat disimpulkan data berdistribusi normal.

2. Uji Hipotesis

Tabel 4 Hasil Uji Hipotesis Penelitian

\begin{tabular}{|l|c|c|c|}
\hline \multicolumn{1}{|c|}{ Variabel } & KoefisienRegresi & Thitung & \multicolumn{1}{c|}{ Sig } \\
\hline Konstanta & 9,988 & 4,676 & 0,000 \\
\hline Pengetahuan & 0,029 & 0,687 & \\
\hline Kesadaran & 0,860 & 15,675 & 0,000 \\
\hline $\mathrm{R} \quad: 0,848$ & & \\
\hline$R$ Square: 0,720 & \multicolumn{5}{|l}{} \\
\hline
\end{tabular}

Berdasarkan tabel 4 di atas, dapat dijelaskan bahwa :

\section{a. Persamaaan Regresi Linier Berganda}

$\mathrm{Y}=\mathrm{a}+\mathrm{b}_{1} \mathrm{X}_{1}+\mathrm{b}_{2} \mathrm{X}_{2}$

$\mathrm{Y}=9,988+0,029 \mathrm{X}_{1}+0,860 \mathrm{X}_{2}$

Persamaan tersebut menunjukkan bahwa konstanta sebesar 9,988. Hal ini menunjukkan bahwa apabila variabel $X_{1}$ dan $\mathrm{X}_{2}$ dianggap nol, maka nilai variabel Kepatuhan dan Kesadaran Wajib Pajak adalah sebesar 9,988satuan. Koefisien regresi $\mathrm{X}_{1}$ sebesar 0,029 menunjukkan bahwa setiap kenaikan Pengetahuan wajib pajak sebesar 1 satuan akan menaikkan kesadaran Wajib Pajak sebesar 0,029 satuan. Koefisien regresi $\mathrm{X}_{2}$ sebesar 0,860 menunjukkan bahwa setiap kenaikan Kesadaran wajib pajak sebesar 1 satuan akan menaikkan kepatuhan Wajib Pajak sebesar 0,860 satuan dan Berdasarkan dari hasil tersebut menunjukkan arah model regresi ini adalah positif. Sehingga menjawab hipotesis $\mathrm{H}_{\mathbf{1}}$ bahwa ada pengaruh positif yang signifikan antara pengetahuan wajib pajak dan kesadaran wajib pajak terhadap kepatuhan wajib pajak dalam membayar Pajak Bumi dan Bangunan (PBB).

\section{b. Koefisien Determinasi}

Hasil nilai koefisien korelasi (R) bernilai positif sebesar 0,848 dan $R$ square $\left(\mathrm{R}^{2}\right)$ sebesar 0,720. Hal ini berarti pengetahuan dan kesadaran wajib pajak memiliki pengaruh positif dan berpengaruh sebesar $72 \%$ terhadap Kepatuhan Wajib 
Pajak, sedangkan sisanya sebesar 28\% dipengaruhi oleh variabel lain di luar penelitian ini, seperti kualitas pelayanan, tingkat penghasilan dan Persepsi wajib pajak terhadap sanksi.

c. Pengaruh Pengetahuan dan Kesadaran Wajib Pajak terhadap Kepatuhan Wajib Pajak dalam Membayar Pajak Bumi dan Bangunan (PBB)

Hasil Penelitian ini menunjukkan bahwa Pengetahuan dan Kesadaran wajib pajak terhadap kepatuhan wajib pajak dalam membayar Pajak Bumi dan Bangunan pada Kantor Badan Pendapatan Daerah (BAPENDA) Kota Pekanbaru berpengaruh. Hal ini dapat dibuktikan dengan nilai t hitung 4,676 yang lebih besar dari $\mathrm{t}$ tabel 3,09019 dengan nilai signifikansi sebesar 0,000 lebih kecil dari 0,05. Nilai koefisien regresi sebesar 0,029 dan 0,860 yang memiliki arah positif menunjukkan semakin baik Pengaruh pengetahuan dan kesadaran wajib pajak dalam membayar Pajak Bumi dan Bangunan maka Kepatuhan Wajib Pajak juga akan baik. Selain itu,berdasarkan hasil koefisien korelasi sebesar 0,848 dan koefisien determinasi $\left(\mathrm{R}^{2}\right) \quad 0,720$ menunjukkan Pengetahuan dan kesadaran wajib pajak berpengaruh terhadap Kepatuhan Wajib Pajak dan mempengaruhi $72 \%$ terhadap Kepatuhan Wajib Pajak, sedangkan sisanya sebesar $28 \%$ dipengaruhi oleh variabel lain di luar penelitian ini.
Pengaruh Pengetahuan dan kesadaran wajib pajak memberikan pengaruh signifikan tetapi tidak dominan terhadap Kepatuhan Wajib Pajak dalam membayar Pajak Bumi dan Bangunan karena Pentingnya tingkat Pengetahuan dan kesadaran wajib pajak merupakan salah satu dari beberapa upaya yang dilakukan dalam meningkatkan kepatuhan wajib pajak dalam membayar Pajak Bumi dan Bangunan (PBB).

\section{SIMPULAN DAN SARAN}

\section{Simpulan}

Penelitian ini bertujuan untuk mengetahui pengaruh tingkat pengetahuan dan kesadaran terhadap kepatuhan wajib pajak dalam membayar Pajak Bumi dan Bangunan (PBB) pada Kantor Badan Pendapatan Daerah (BAPENDA) Kota Pekanbaru. Berdasarkan hasil analisis yang telah diuraikan sebelumnya, maka dapat disimpulkan penelitian ini mendukung hipotesis yang diajukan. Penjelasan rincinya yaitu sebagai berikut.

1. Tingkat pengetahuan dan kesadaran wajib pajak berpengaruh positif terhadap kepatuhan wajib pajak. Hasil ini sejalan dengan penelitian Febriani Ramadhani Juwanti Pada tahun 2017. Hal ini dibuktikan melalui analisis regresi linier berganda yang diperoleh nilai Adjusted $R$ Square sebesar 0,720, yang dapat diartikan bahwa pengaruh Pengaruh pengetahuan dan kesadaran wajib pajak terhadap Kepatuhan Wajib Pajak adalah 72\%, sedangkan sisanya sebesar $28 \%$ dipengaruhi oleh 
variabel lain di luar penelitian ini, seperti kualitas pelayanan,tingkat penghasilan dan Persepsi wajib pajak terhadap sanksi.

2. Hasil uji t statistik menghasilkan nilai signifikansi lebih kecil dari of significant yaitu $0,000<0,05$. Besarnya nilai koefisien regresi $X_{1} \quad 0,029$ dan $X_{2} \quad 0,860$ dengan bilangan kostanta 9,988. Persamaan garis regresinya adalah $\mathrm{Y}=9,988-0,029 \mathrm{X}_{1}-0,860$ $\mathrm{X}_{2}$. Hal ini berarti semakin tinggi tingkat pengetahuan dan kesadaran wajib pajak maka semakin tinggi Kepatuhan Wajib Pajak.

\section{Saran}

Berdasarkan kesimpulan dari penelitian ini, dapat dikemukakan saran-saran sebagai berikut:

\section{Bagi Pemerintah}

Hasil penelitian ini diharapkan pemerintah dapat meningkatkan sosialisasi perpajakan pada masyarakat dan meningkatkan pelayanan yang berkaitan dengan informasi maupun administrasi pajak, Sehingga wajib pajak tahu kapan harus membayar dan terhindar dari sanksi perpajakan. Hal ini diharapkan dapat menigkatkan kesadaran masyarakat, dan akan meningkatkan kepatuhan wajib pajak sehingga akan berdampak langsung kepada penerimaan negara.

2. Bagi Kantor Badan Pendapatan Daerah Kota Pekanbaru

Badan Pendapatan Daerah Kota Pekanbaru Tampan sebaiknya memberikan sosialisasi dan penyuluhan lebih lanjut kepada para wajib pajak untuk lebih menungatkan pengetahuan dan kesadaran dari wajib pajak.

3. Bagi Wajib Pajak

a. Disarankan kepada wajib pajak untuk bisa aktif lagi dalam menggali informasi mengenai perpajakan dikarenakan saat ini sudah banyak faktor pendukung seperti sistem dan layanan yang mempermudah dalam pelaporan wajib pajak agar menjadi wajib pajak patuh.

b. Wajib pajak untuk bisa lebih taat dan patuh lagi pada peraturan perpajakan untuk menjalankan tanggung jawabnya demi meningkatkan kepatuhan wajib pajak.

4. Bagi Peneliti Selanjutnya

Bagi peneliti selanjutnya yang tertarik dengan topik penelitian yang ini, agar meneliti pengaruh pengetahuan dan kesadaran wajib pajak lebih mendalam atau lebih spesifik lagi serta memperluas cakupan responden baik dari cakupan wilayah maupun jenis wajib pajaknya. 


\section{DAFTAR PUSTAKA}

Amanah, D. D. 2015. Strategi pemungutan PBB sebagai upaya meningkatkan Pendapatan Asli Daerah di Kota Mojokerto. Jurnal Ilmu \& RisetAkuntansi, Vol. 4 No. 11.

Ghozali, I. 2016. Aplikasi analisis multivariate dengan program SPSS 23 (EdisiKelima). Semarang: Badan Penerbit Universitas Diponegoro .

Hidayanti, S. d. 2011. Pelimpahan Pajak Bumi dan Bangunan Sektor Pedesaan dan Perkotaan (PBB P-2) dan Bea Perolehan Hak atas Tanah (BPHTB) menjadi Pajak Daerah, antara peluang dan tantangan. Jurnal WIGA, 2088-0944.

Irianto, Edi Slamet, 2012. Pajak Negara dan Demokrasi. Yogyakarta: Laksbang Mediatama.

Jati, I. G.2016. Pengaruh sikap, kesadaran wajib pajak dan pengetahuan perpajakan pada kepatuhan membayar pajak bumi dan bangunan. E-JurnalAkuntansi Universitas Udayana, 1510-1535.

Jatmiko, Agus Nugroho. 2011. Pengaruh Sikap Wajib Pajak pada Pelaksanaan Sanksi Denda, Pelayanan Fiskus, dan Kesadaran Perpajakan terhadap Kepatuhan Wajib Pajak Studi Empiris Terhadap Wajib Pajak Orang Pribadi di Kota Semarang. Universitas Diponegoro: Tesis Magister Akuntansi.

Purnamasari, Apriani. S. d. 2016. Pengaruh pemahaman, sanksi perpajakan, tingkat kepercayaan pada pemerintah dan hukum, serta nasionalisme terhadap kepatuhan wajib Pajak dalam membayar PBB-P2 (Studi pada wajib pajak PBB-P2 di Kota Banjar, Jawa Barat). Jurnal UniversitasSoedirman.
Rahayu, S. K. 2010. Perpajakan indonesia. Yogyakarta: Salemba Empat.

Rahmawan, E. (2012). Optimalisasi pemungutan pajak bumi dan bangunan (PBB) dalam peningkatan pendapatan daerah (Studi pemungutan pajak bumi dan bangunan (PBB) di Kecamatan Limpasu Kabupaten Hulu Sungai Tengah). Jurnal Ilmu Politik dan Pemerintahan Lokal.

Sugiyono. 2010. Metode Penelitian Pendidikan Pendekatan Kuantitatif, Kualitatif, dan R\&D. Bandung: Alfabeta.

Tjahjono. 2008. Pengaruh tingkat kepuasan atas pelayanan perpajakan terhadap tingkat kepatuhan wajib pajak orang pribadi pada kantor Wilayah Direktorat Jenderal Pajak Jawa Timur Bagian Timur I. Jurnal UniversitasAirlangga.

Tjiptohadi, T. d. 2015. Kepercayaan wajib pajak terhadap fiskus, kesadaran wajib pajak terhadap pentingya membayar pajak, rekayasa akuntansi dan kepatuhan wajib pajak. Jurnal Manajemen.

Yusnidar, Johan. S. d. 2015. Pengaruh faktor-faktor yang mempengaruhi kepatuhan wajib pajak dalam melakukan pembayaran pajak bumi dan bangunan perdesaan dan perkotaan (Studi pada wajib pajak PBB-P2 Kecamatan Jombang Kabupaten Jombang). Universitas Brawijaya. 